Jpn. J. Hosp. Pharm.

$\left[\begin{array}{cc}\text { 料 } \\ \text { 盗 } \\ \text { (1) } 80-83 \text { (1993) }\end{array}\right]$

\title{
トコンシロップ中のエメチン，セファエリンの定量法について
}

\author{
手嶋大輔*, 青山敏信 \\ 九州大学医学部附属病院薬剤部
}

\section{Quantitative Analysis of Emetine and Cephaeline in Ipecac Syrup}

\author{
Daisuke Teshima* and Toshinobu Aoyama \\ Department of Hospital Pharmacy, Faculty of Medicine, Kyushu University $\dagger$
}

(Received March 25, 1992 )

(Accepted August 27, 1992)

\begin{abstract}
We established an easy and quick determination method of emetine (EM) and cephaeline (CP) in ipecac syrup by HPLC, which was carried out by using chloroquine as an internal standard. The calibration plots of these alkaloids showed a good linearity. Semi-preparative HPLC followed by mass-spectrometry was employed and the spectra of EM and CP isolated by preparative HPLC were found to be identical with those of authentic samples. Constant amounts of EM and $\mathrm{CP}$ were added to samples and the recovery rates were determined. This method gave a good recovery. The total contents of EM and CP in ipecac syrup from the USA ranged 153.2-184.9 $\mathrm{mg} / 100 \mathrm{ml}$ and the content ratios $(\mathrm{CP} / \mathrm{EM})$ were $2.6-3.0$. These levels were higher than those of the USP standard for ipecac syrup.
\end{abstract}

Keywords_-ipecac syrup; emetine; cephaeline; high performance liquid chromatography

欧米に括いて,トコンは催吐剤, 抗アメーバ赤 痢薬, 去痰剤として広く使用されている ${ }^{1,2)}$. 特 に，幼児の誤领事故に対する催吐剤としてトュン シロップが繁用されている3). 一方，日本におい ては,トコンは催吐剤としてではなく, 去痰剤, 抗アメーバ赤莉薬として長年使用されてきだ). ところが，最近になってトコンシロップが救急医 療の場で注目され, いくつかの病院で使用され始 めている5).

トコンには, エメチン (EM), セファエリン (CP)，サイコトリン， 0-メチルサイコトリン, エメタミン, イペカミンなど数多くのアルカロイ ドが含まれている，EM，CP が主成分であり

$\dagger$ 福岡市東区馬出3-1-1; 3-1-1, Maidasi, Higashiku, Fukuoka, 812 Japan
(Fig. 1)，催吐作用はこの両者によって引き起こ される、また，CP の催吐作用は EM の 2 倍とい われている. トコンシロップ中の EM, CP の分 離定量法は米局方に規定されているが，操作が煩 雑なため, 将来わが国にトコンシロップを導入す るにあたり，その分離定量法の確立は品質管理上 必要と考えられる.トコンアルカロイドの定量法 としては, 薄層クロマトグラフィー (TLC $)^{6,7)}$, TLC デンシトメトリー8,9), 高速液体クロマトグ ラフィー(HPLC) $)^{9-11)}$, カラムクロマトグラフィ 一と分光光度法を組み合わせた方法 ${ }^{1)}$ などが報告 されている。

そこで, 著者らは HPLCを用いたトコンシロ ップ中の EM, CP の簡易定量法を確立し, 米国 製トコンシロップの品質について検討を行った. 


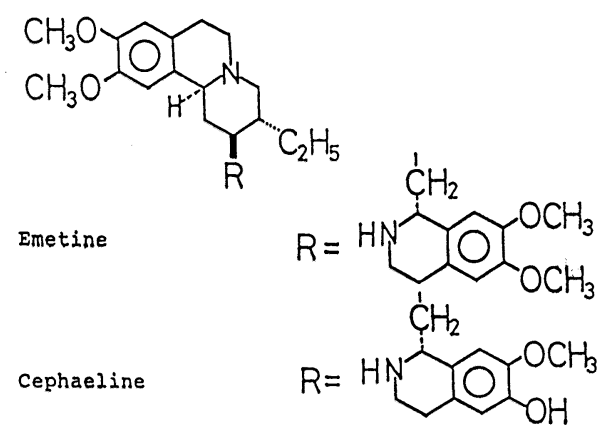

Fig. 1. Chemical Structures of Emetine and Cephaeline

\section{実験材料および方法}

\section{1. 材 料}

米国より購入した市販トコンシロップ（Prepac Pharm. C., Barre Drug Co. 製) を使用 した.

\section{2. 試 薬}

特に述べるもの以外は，すべて市販の特級試薬 を使用した。

\section{3. 標 品}

$\mathrm{EM}$ は, シグマ社より購入した。 CP の純度 は, 前報に従い92, 日局トコン末から単離, 精製

し, TLC, マススペクトル (electron ionization MS, JEOL JMS-D300), 拉よび核磁気共鳴スペ クトル (proton NMR, JEOL JNM-GX270, 270MHZ)によって同定した.

\section{HPLC}

試料の調製：トコンシロップ $200 \mu 1$ を正確に量

り, 蒸留水 $4 \mathrm{ml}$ および内部標準 溶 液（クロロキ

ン $6 \mathrm{mg} / \mathrm{ml}$ ) $200 \mu \mathrm{l}$ を加えて試料とした.

測定条件：以下の装置および条件で測定した。

装置：島津 LC-3A

検出器: UV (島津 SPD-2A)

検出波長： $285 \mathrm{~nm}$

カラム : TSK gel ODS-80TM $(5 \mu \mathrm{m}, 15 \mathrm{~cm}$

\section{$\times 4.6 \mathrm{~mm} ; \mathrm{TOSOH}$ )}

温度 : $25^{\circ} \mathrm{C}$

移動相：10mM sodium 1-heptanesulfonate (adjusted $\mathrm{pH} 4$ with $\mathrm{CH}_{3} \mathrm{COOM}$ ) : $\mathrm{MeOH}=$ $46: 54(\mathrm{v} / \mathrm{v})$

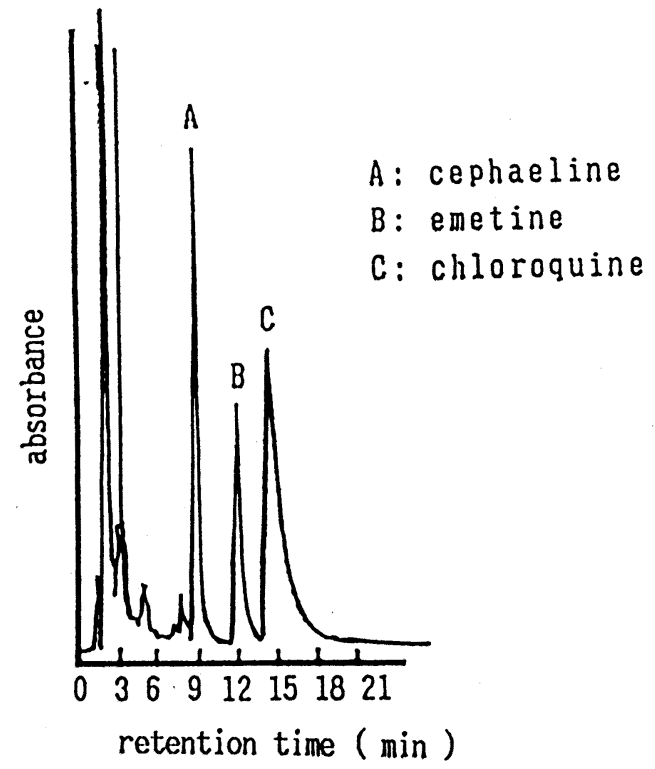

Fig. 2. HPLC of Ipecac Syrup and Chloroquine

流速 $: 1.0 \mathrm{ml} / \mathrm{min}$

注入量 : $20 \mu 1$

\section{5. 検量線の作成}

標準溶液は, $1 \mathrm{ml}$ 中に $\mathrm{EM}, \mathrm{CP}$ をそれ゙れ 25 - $90 \mu \mathrm{g}$ 含むように調製 した。 その $4.2 \mathrm{ml}$ をと り, 内部標準 (I.S.) 溶液 (クロロキン $6 \mathrm{mg} / \mathrm{ml}$ ) $200 \mu 1$ を添加し，その $20 \mu 1$ をPLCに注入した。 得られたクロマトグラムの I.S. に対する EM, $\mathrm{CP}$ のピーク高さの比より検量線を作成した.

\section{6. マススペクトロメトリー}

試料 $20 \mu 1$ を HPLC に注入し，EM，CP に相 当する各流出液をそれぞれ分取する，この操作を 20回繰り返し行い, 各流出液をまとめて減圧下濃 縮する. 次に, EMフラクションはェーテルで, $\mathrm{CP}$ フラクションはクロロホルムで抽出を行い, 再度減圧下濃縮乾固させる. 得られた残渣の electron ionization MS を測定した.

\section{結果および考察}

Fig.2 にクロマトグラムを示す．保持時間は, $\mathrm{CP}$ が 9.1 分, $\mathrm{EM}$ が 12.3 分, 内部標準のクロロ キンが 15.1 分で, 各ピークの分離は良好であっ た. 


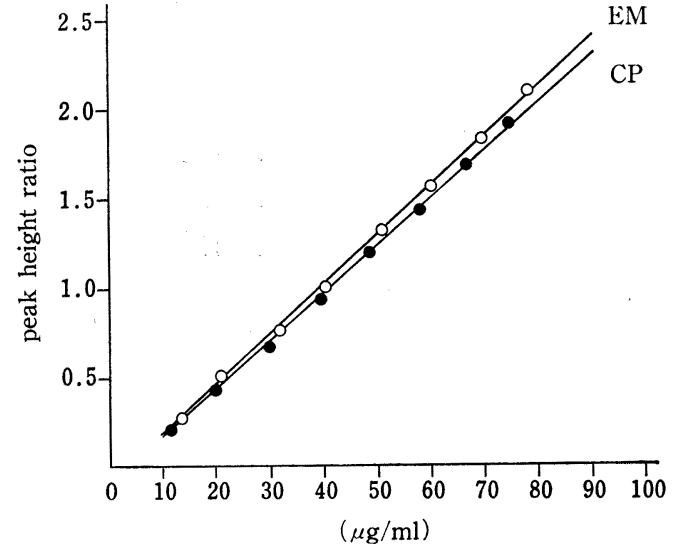

Fig. 3. Calibration Curves of Emetine (EM) and Cephaeline (CP)

$\mathrm{EM}, \mathrm{CP}$ の 2 個のピークを同定するため，各 ピークに相当する流出液を分取し，マススペクト
ルを測定した。単離された各ピークのスペクトル は, 親イオンピーク $\mathrm{m} / \mathrm{z} 480(\mathrm{EM}), 466$ (CP) が認められ，フラグメントイオン $\mathrm{m} / \mathrm{z}$ 192, 205, 272, 288 (EM), 178, 192, 272, 288 (CP) も標 品および文献值と一致した。

クロマトグラムより得られた I.S. に対する $\mathrm{E}$ $\mathrm{M}, \mathrm{CP}$ のピーク高さ比は，20-80 $\mu \mathrm{g}$ の濃度範囲 で良好な直 線 関 係（相関係数 0.999）を示した (Fig. 3).

トコンシロップに一定量の $\mathrm{EM} ， \mathrm{CP}$ を添加し 回収率を求めた. Table 1 飞結果を示す.

EM 99.5\%，CP 105.2\% と良好な結果が得ら れた。 したがって，本測定法はトコンシロップの 定量法として十分応用できることが実証された。 また，米局方によるトコンシロップの定量法に比 へ，本法は簡易，迅速性の点からより実用的な方

Table 1. Recovery of EM and CP from Ipecac Syrup

\begin{tabular}{|c|c|c|c|c|c|c|c|c|c|c|}
\hline & \multicolumn{5}{|c|}{ EM } & \multicolumn{5}{|c|}{$\mathrm{CP}$} \\
\hline & 1 & 2 & 3 & 4 & 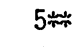 & 1 & 2 & 3 & 4 & 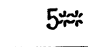 \\
\hline $\begin{array}{l}\text { content of alkaloid in } \\
\text { ipecac syrup }(\mathrm{m} / 100 \mathrm{ml}) *\end{array}$ & 47.8 & 45.1 & 45.4 & 45.4 & 42.1 & 137.1 & 130.3 & 135.4 & 137.4 & 111.1 \\
\hline $\begin{array}{l}\text { added alkaloid to } \\
\text { ipecac syrup (m\&/100ml) }\end{array}$ & 36.2 & 36.2 & 36.2 & 36.2 & 36.2 & 34.6 & 34.6 & 34.6 & 34.6 & 34.6 \\
\hline $\begin{array}{l}\text { found alkaloid in } \\
\text { ipecac syrup (mg/100ml) }\end{array}$ & 80.9 & 79.3 & 82.6 & 82.6 & 79.3 & 175.9 & 171.8 & 184.2 & 181.8 & 153.4 \\
\hline recovery $(\%)$ & 96.3 & 97.5 & 101.2 & 101.2 & 101.3 & 102.4 & 104.2 & 108.4 & 105.7 & 105.3 \\
\hline meam $\pm S D$ & & 99. & 1 & & & & & . & & \\
\hline
\end{tabular}

* reference to Table. II.

** Sample No.. (Number 1-4 are from different lots of the Prepac Pharm. Co..)

Table 2. Contents of EM and CP in USP-Ipecac Syrup (mg/100ml)

\begin{tabular}{|c|c|c|c|c|}
\hline $\begin{array}{c}\text { sample } \\
\text { No. }\end{array}$ & $\frac{E M}{\text { mean } \pm S D^{a}}$ & $\frac{C P}{\left.\operatorname{mean} \pm S D^{a}\right)}$ & total content & $\begin{array}{c}\text { ratio } \\
(\mathrm{CP} / \mathrm{EM})\end{array}$ \\
\hline $\begin{array}{l}1 \\
2 \\
3 \\
4 \\
5\end{array}$ & $\begin{array}{l}47.8 \pm 0.3 \\
15.1 \pm 0.7 \\
45.4 \pm 0.8 \\
45.4 \pm 0.5 \\
42.1 \pm 0.1\end{array}$ & $\begin{array}{l}137.1 \pm 1.1 \\
130.3 \pm 2.1 \\
135.4 \pm 2.0 \\
137.4 \pm 1.8 \\
111.1 \pm 1.2\end{array}$ & $\begin{array}{l}184.9 \\
175.4 \\
180.8 \\
182.8 \\
153.2\end{array}$ & $\begin{array}{l}2.87 \\
2.89 \\
2.98 \\
3.03 \\
2.64\end{array}$ \\
\hline
\end{tabular}

Sample No. 1-4 are from different lots of the Prepac Pharm. Co.. a) $n=5$ 
法と考えられる.

次に, 米国より購入したトコンシロップ 5 種類 について定量を実際に HPLCを用いて行った. 結果を Table 2 に示す. EM, CP の総含量は, $153.2-184.9 \mathrm{mg} / 100 \mathrm{ml}$ で, 含量比 (CP/EM) は2.6-3.0であった. CP の催吐作用は EM の約 2 倍といわれていることを考台合わせると，米局 方トコンシロップの催吐作用にはかなりの差が生 じることが予想される. したがって，トコンシロ ップを米国より購入する場合には, 品質をチェッ クする必要があると考えられる，また，日局トコ ン末を使用してトコンシロップを調製する場合に も, EM, CP 含量のバラッキが十分考えられる ので，品質管理を行うことは不可欠と考えられ る.

\section{引用文献}

1) U.S.P XXII, 1990, p.717-719.

2) B.P., 1988, p.316-317.

3) E.P.Krenzelok and B.S.Dean, Clinical Pharmacy, 6, 715-717 (1987).

4) 日局XII, 1991, D683-686.

5）山下 衛, 中村紘一, 水谷太郎, 小山定二, 内藤 裕史, 救急医学, 10, 219-224 (1986).

6) M. S. Habib and K. J. Harkiss, J. Pharm. Pharmacol., 21 (Suppl.), 57s-59s (1969).

7) M.S.Habib, Planta Med.,27, 294-297 (1975).

8）高橋一德, 大野昌子, 衛生試験所報告, 97, 21-24 (1979).

9）手嶋大輔，土谷隆紀，青山敏信，堀岡正義，医薬 品研究, 15, 63-71 (1984).

10) N.P.Sahn and S.B. Mahato, J. Chromatogr., 238, 525-529 (1982).

11）鈴木良雄, 安生呫枝子, 近藤由利子, 熊谷健伸, 病院薬学, 15 (1), 1-4 (1989). 